ScIDoC

International Journal of Dentistry and Oral Science (IJDOS)

ISSN: 2377-8075

\title{
The Influence of Mind Mapping Method in Dental Hygiene Education towards Knowledge of Primary School Students in Banda Aceh, Indonesia
}

Research Article

Ainun Mardiah ${ }^{1 *}$, Reca $^{2}$, Ratna Wilis ${ }^{3}$, Salikun $^{4}$

${ }^{1}$ Department of Dental Therapy and Hygiene, PoltekkesKemenkes Aceh, Banda Aceh 23231, Indonesia.

${ }^{2}$ Department of Dental Therapy and Hygiene, PoltekkesKemenkes Aceh Banda Aceh 23231, Indonesia.

${ }^{3}$ Department of Dental Therapy and Hygiene, PoltekkesKemenkes Aceh, Banda Aceh 23231, Indonesia.

${ }^{4}$ Department of Dental Therapy and Hygiene, PoltekkesKemenkes Semarang, 50268, Indonesia.

\section{Abstract}

Background: One of the efforts to improve dental hygiene in children is to carry out educational activities. Mind mapping is among the types of an easy way for primary school students to understand the information through interesting pictures, symbols, or keywords that do not bore the students. The aim of study is to determine the influence of dental hygiene education with mind mapping method towards the knowledge of primary school students, specifically fourth-graders inIslamic Elementary School (MIN) of Mesjid Raya Kota Banda Aceh, Indonesia.

Method: This type of research is a quasi-experiment with pre and post-test design with one group design. The study was conducted with 49 respondents. The data collection techniques was in the form of questionnaires about dental and oral hygiene knowledge. Having CI: 95\% for a dependent T-test enabled us to do the data analysis.

Results: The comparison value has been found that after the implementation of the mind mapping method, $89.4 \%$ of the student's knowledge increased. Comparing to that of before using mind mapping, there was just $12.8 \%$. The result has further strengthened our confidence that there is an increase in students' knowledge by mind mapping methods for dental hygiene education. Furthermore, the statistical test results obtained a p-value of $0.000(<0.05)$ which confirms the presence of influence.

Conclusion: On combining the results, we conclude that there is an influence of the mind mapping method towards dental hygiene knowledge of the students.

Keywords: Mind Mapping; Knowledge; Dental Hygiene; Students; Banda Aceh.

\section{Introduction}

Health education, in the sense of education in general, is any planned effort to influence people, either individual or the community, so that they do what health practitioners expect. This definition implies the input elements (target and educators of education), processes (planned efforts to influence people), and output (doing what is expected). The expected outcome of health promotion is health behavior, or behavior to maintain conducive health for the goal of health promotion [1, 2].

Previous dental and oral hygiene education efforts have been carried out using various methods of lectures such as tooth brushing learning [3-6] and audio-visual media [7-10]. These methods are generally cannot take the attention of the children. They tend to like something interesting, attractive, and directly practiced so that it will be easy to remember and be accepted. Health education methods through schemes and pictures are often preferred so that they are more easily understand. Such a method is called mind mapping $[11,12]$.

Mind mapping is a creative and effective way of taking notes and will literally map our thoughts. Notes created form interrelated ideas, with the main topic in the middle and sub-topics and they will breakdown into branches. The benefits of drawing and text someone to record or issue an idea that is in the mind, then we have used the two hemispheres of the brain synergistically. Mind Mapping is the easiest way to put some information into the brain

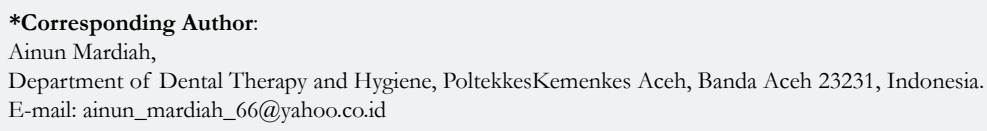

Citation: Ainun Mardiah, Reca, Ratna Wilis, Salikun. The Influence of Mind Mapping Method in Dental Hygiene Education towards Knowledge of Primary School Students in Banda Aceh, Indonesia. Int J Dentistry Oral Sci. 2021;8(1):1325-1328. doi: http://dx.doi.org/10.19070/2377-8075-21000262

Copyright: Ainun Mardiah ${ }^{\circ}$ 2021. This is an open-access article distributed under the terms of the Creative Commons Attribution License, which permits unrestricted use, distribution and reproduction in any medium, provided the original author and source are credited. 
and take information out of it. The uniqueness of mind mapping occurs because every human being including children has different radiance (mindset, imagination, understanding, creativity, process information) $[13,14]$.

Through mind mapping, it allows students to make connections, see patterns, access related memory that has been previously stored, and develop memory paths that already exist. This mind map activity involves hand movements to create maps, paths, and connections between concepts. The process of continuous hand movements to connect this concept can improve the work of the brain in students so that the ability to understand concepts in the subject matter can be obtained maximally. For students with kinesthetic learning styles, the more body movement in the learning process, the more information will be gained.

It is explained that the mapping concept consists of several parts. The first is preparation. The specific step in the research investigators outline the research goals, which could be first, obtaining a participant. The second step is generation in which in this step, there is a brainstorming group to collect information from the participant according to the questions proposed. The third is structuring. In the structuring step, the separation is done with sorting-and-rating sessions to gain a better understanding of how items are related to one another. The fourth, representation which is computerized analysis to summarize the data into concept maps. This step is divided into the participant-processing stage and the researcher-processing stage. The fifth is interpretation in which the participants are invited for sorting-and-rating sessions to address the goal of researchers exploring the participant. The last step is utilization. The researchers reconvene to discuss the findings upon the completion of data collection and analysis [15].

Based on the data from the Baiturrahman Community Health Center, 560 cases of caries were found in 15 elementary schools including Islamic Elementary School (MIN) Mesjid Raya in Banda Aceh City, Indonesia. The highest percentage of caries rates was MIN Mesjid Raya in Banda Aceh, as many as 50 caries cases out of 80 people. Based on the results of interviews with 15 students, 10 of whom have poor knowledge about dental and oral hygiene. Hence, the researchers are interested in examining the effect of the mind mapping method on school-age children's knowledge in terms of dental and oral health. The purpose of this study is to analyze the effect of mind mapping methods on dental and oral health knowledge of Grade IV in MIN Mesjid Raya Banda Aceh
City.

\section{Materials and Methods}

The type of this research is a quasi-experiment, in which students are given treatment in the form of a dental hygiene mind mapping method. We used a pre and post-test design with One Group Design, which the treatment will be done in one group. This research was conducted at MIN Mesjid Raya Banda Aceh City. The population in this study were all $4^{\text {th }}$-grade students with 47 students. The sampling technique was with a total sampling technique.

The scope of the research is dental hygiene knowledge including what is dental hygiene, dental and oral disease, and how to take care of our teeth by using mind-mapping methods so that it can determine its effect on dental and oral health knowledge of fourth-grade students at MIN Mesjid Raya Banda Aceh City.

The research was analyzed using the univariate and bivariate technique. Univariate analysis is intended to see an overview of the independent variables, namely education of mind mapping of dental and oral health both before and after each treatment shown by tabulation and description. On the other hand, bivariate analysis is done to understand the influence of the mind mapping method in dental and oral health by paired t-test.

\section{Results}

The respondents in this research were divided into several category, i.e. general data and specific data. General data consists of age and gender while the specific data consists of univariate withsub of knowledge level of the students before and after the treatment of mind mapping. Apart from univariate, there is variate analysis, which obtain the influence of mind mapping method. The following tables show the statistical number related to this research. Table 1 shows the highest number of respondents based on age is 10 years with 39 students $(83.0 \%)$.

Table 2 shows the highest number of respondents by gender is male group with 29 students $(61.7 \%)$, while the female students are only 18 people $(38.3 \%)$.

Table 3 shows the level of student knowledge before the implementation of mind mapping method is $46.8 \%$ in the fair category, $40.1 \%$ of the level of knowledge is bad, while those included in

Table 1. Frequency Distribution of Respondent based on Age.

\begin{tabular}{|c|c|c|}
\hline Age & $\mathbf{N}$ & Percentage $\mathbf{( \% )}$ \\
\hline 10 years old & 39 & 83.0 \\
\hline 11 years old & 8 & 17.0 \\
\hline Total & 47 & 100 \\
\hline
\end{tabular}

Table 2. Frequency Distribution of Respondent based on Gender.

\begin{tabular}{|c|c|c|}
\hline Gender & $\mathbf{N}$ & Percentage (\%) \\
\hline Male & 29 & 61.7 \\
\hline Female & 18 & 38.3 \\
\hline Total & 47 & 100 \\
\hline
\end{tabular}


Table 3. Knowledge Level before Implementation of Mind Mapping.

\begin{tabular}{|c|c|c|}
\hline Knowledge & $\mathbf{N}$ & Percentage (\%) \\
\hline Good & 6 & 12.8 \\
\hline Fair & 22 & 46.8 \\
\hline Bad & 19 & 40.4 \\
\hline Total & 47 & 100 \\
\hline
\end{tabular}

Table 4. Knowledge Level after implementation of Mind Mapping Method.

\begin{tabular}{|c|c|c|}
\hline Knowledge & $\mathbf{N}$ & Percentage (\%) \\
\hline Good & 42 & 89.4 \\
\hline Fair & 3 & 6.4 \\
\hline Bad & 2 & 4.2 \\
\hline Total & 47 & 100 \\
\hline
\end{tabular}

Table 5. Mind Mapping Influence towards Knowledge Level.

\begin{tabular}{|c|c|c|c|}
\hline Variable & Mean & R calculation & P value \\
\hline Pre-test & 58.09 & $-11,339$ & 0.000 \\
\hline Post-test & 90.00 & & \\
\hline
\end{tabular}

the good category are only $12.8 \%$.

Table 4 shows the level of knowledge after an educational mind mapping method was implemented. It increased to $89.4 \%$ for good category, fair level by $6.4 \%$ while those with bad knowledge level were only $4.2 \%$.

The results of the study as presented in Table 5 noted that the knowledge of students after the mind mapping method is greater than before it was carried out. This showed an increase in the knowledge level of the students about oral health. Statistical test results obtained the value of $\mathrm{P}=0,000(\mathrm{p}=<0.05)$ so that at $\mathrm{CI}$ : $95 \% \mathrm{Ho}$ is rejected and $\mathrm{Ha}$ is accepted. Therefore, it can be concluded that at the $95 \%$ significance level, there is an influence of students' knowledge before and after the mind mapping method of oral and dental hygiene.

\section{Discussion}

According to the research data has been obtained, the results of statistical tests was significant $\mathrm{p}=0,000(<0.05)$ at a $95 \%$ confidence level. Thus, it can be concluded that there was a significant influence between students' knowledge before and after the mind mapping method about dental and oral hygiene at MIN Mesjid Raya Banda Aceh City.

The use of mind mapping methods with images and colors will make students more interested and remember material about oral health. Therefore, students' knowledge will be better after the mind mapping methods was applied. One way that can be used to improve knowledge and learning skills is by using the mind mapping method. Mind mapping was chosen because it is one of the effective and efficient learning methods in which there are aspects of learning skills encompasses taking notes and remembering. This is in line with the previous conducted research which stated that the mind map method is more effective than tradi- tional methods [16]. Mind mapping can help students in learning and increase knowledge so that they will be more successful in learning. This is supported by the results of the previous research which concludes that there is an increase in student learning outcomes through the application of mind mapping type cooperative learning models [17]. Research that tested the mind mapping method with learning skills was conducted, it stated that the mind map technique with the mind mapping method was effective to increase students' knowledge [18]. Learning methods with mind mapping are very suitable to develop children's thinking abilities. Mind Mapping is the easiest way to put information into the brain [19]. Mind mapping is a creative, effective, and literally literate way to "map" our thoughts. Mind mapping is a good method used as a tool for health education that involves cognitive, effective and psychomotor components. By utilizing symbols, pictures and colors when a child brings out an idea that is in his mind, the child has used the two hemispheres of the brain synergistically [20]. Mind mapping will help the students to learn information since such a learning method gives them a force to organize and put images as well as color to it [21].

Mind mapping has many benefits. First, it is flexible. When the teacher or others explain the material, students easily add it in the appropriate place in their Mind mapping without confusion. Second, it makes the student stay focus and pay attention because Mind mapping does not make students capture every word explained from the teacher or others, rather simply capture the main ideas conveyed. Third, it helps to improve our understanding. Fourth, it is such a fun learning because Mind mapping combines unlimited creativity and imagination of students, this is more exciting when compared to taking regular notes [22]. This is in line with research conducted stated that there is a significant difference between the results of the pretest and posttest in the experimental group with $\mathrm{p}=0.020$ so that the mind mapping method can improve learning outcomes of integrated natural science subjects [23]. 
An experimental design of mapping was also used towards nursing students in which successfully support as a cognitive tool to enhance students' critical thinking (CT) in the way of encouraging them to explore the information. Besides, a paired t-test was also used to identify whether the method brings betterment. The betterment is brought as the paired t-test showed the significant improvement for the students according to the value of $\mathrm{P}<0.001$ [24].

The results of the research conducted also stated there was an influence of the application of the mind mapping experimental method to increasing knowledge $[25,26]$. The results showed there was a significant influence in the application of mind mapping learning models to the learning outcomes of grade IV students of SDN 2 TanjungSenang. Mind map that was used as a treatment in this research was a form of learning strategy to understand the material by using notes as an external memory aid. Human memory is easier to store information in the form of images with long periods of time. The results of creating mind maps therefore can be used as external learning aids so that they can be reviewed easily rather than reread as a whole. Making notes can function as a memory aid that is external [27]. Mind mapping is effective to improve the results of Junior High School student knowledge because there are advantages of using mind mapping in class. It allows students to focus on the subject, give a clear picture as a whole in one paper, and provide details as well as group the concepts and compare them.

\section{Conclusion}

According to the results, the level of knowledge of students before the mind mapping method was $46.8 \%$ in the fair category, and $40.1 \%$ had poor level of knowledge, while those in the good category were only $12.8 \%$. After the educational mind mapping method was applied, the level of knowledge of students showed an increase as much as $89.4 \%$ in good category, $6.4 \%$ in fair category, while those with less knowledge were only $4.2 \%$.

\section{Acknowledgement}

We would like to thank PoltekkesKemenkes Aceh and Poltekkes Kemenkes Semarang for the source of support. The source of funding for this research came from self-funds. The authors declare that they have no conflict of interest.

\section{References}

[1]. Kumar S, Preetha G. Health promotion: an effective tool for global health. Indian J Community Med. 2012 Jan;37(1):5-12. Pubmed PMID: 22529532 .

[2]. Fuad Husain Akbar, Annisa, Yoris Adi Maretta. The Influence of Quality of Dental Health Services on Trust in West Sulawesi Province, Indonesia. Int J Dentistry Oral Sci. 2020;7(7):770-775.

[3]. Makuch A, Reschke K, Rupf S. Effective teaching of tooth-brushing to preschool children. J Dent Child (Chic). 2011 Jan-Apr;78(1):9-12. Pubmed PMID: 22041002

[4]. Ceyhan D, Akdik C, Kirzioglu Z. An educational programme designed for the evaluation of effectiveness of two tooth brushing techniques in preschool children. Eur J Paediatr Dent. 2018 Sep;19(3):181-186. Pubmed PMID: 30063148
[5]. Al-Qahtani SM, Razak PA, Khan SD. Knowledge and Practice of Preventive Measures for Oral Health Care among Male Intermediate Schoolchildren in Abha, Saudi Arabia. Int J Environ Res Public Health. 2020 Jan 21;17(3):703. Pubmed PMID: 31973187.

[6]. Deinzer R, Cordes O, Weber J, Hassebrauck L, Weik U, Krämer N, et al. Toothbrushing behavior in children - an observational study of toothbrushing performance in 12 year olds. BMC Oral Health. 2019 Apr 29;19(1):68. Pubmed PMID: 31035974.

[7]. Anwar AI, Zulkifli A, Syafar M, Jafar N. Effectiveness of counseling with cartoon animation audio-visual methods in increasing tooth brushing knowledge children ages 10-12 years. Enferm Clin. 2020 Mar;30 Suppl 2:285288. English, Spanish. Pubmed PMID: 32204167.

[8]. Jain DS, JAIN M, KHAN K, PANDEY A, BAGBAN A. Evaluation the us of Audio Visual Aids in Knowledge Gained by Patients Visiting a Dental College in Greater Noida. International Health care Research Journal. 2017;9:278-83.

[9]. Mohammed RB, Rasool SM, Meenakshi K, Yasmeen SA, Anusha K, Guddala NR. Assessment of Studentâ s Perceptions for Audio-visual Aids in Dentistry. Annals of Medical and Health Sciences Research. 2017;7(4).

[10]. Izham Akmal NL, Ganapathy D, Visalakshi RM. Effects of audio-visual aids on convincing patients for dental treatment-A review. Drug Invention Today. 2019 May 15;12(5).

[11]. Yang H, Gao XB, Li MH, Ye Q, Sun Y, Huang Y. The use of mind mapping in health education in extended care for children with caries. J Int Med Res. 2020 May;48(5):300060519898053. Pubmed PMID: 32468883.

[12]. Bhat PK, VJ NM, Jayachandra MY, Krishna VG, Aruna CN, Nayana M. "Mind Mapping - A Learning Stategi among Dental Students: A Comparative Study," IntJ Sci Res.2019 Jul 8;8(5).

[13]. Swadarma D. Penerapan mind mapping dalam kurikulum pembelajaran. Elex Media Komputindo; 2013 Sep 30.

[14]. Sassenberg K, Vliek ML, editors. Social Psychology in Action: EvidenceBased Interventions from Theory to Practice. Springer; 2019 Jul 1; 179-191. https://scholar.google.com/scholar?hl=en\&as_sdt=0\%2C5\&q=Mindset+Theory $\% 2 \mathrm{C} \% \mathrm{E} 2 \% 80 \% 9 \mathrm{D}+\mathrm{in}+$ Social + Psychology+in+Action $\% 3 \mathrm{~A}+$ Evidenc e-Based+Interventions+from+Theory+to+Practice\%2C+K.+Sassenb.\%2C + Cham $\% 2 \mathrm{C}+$ Switzerland\&btnG=

[15]. Burke JG, O'Campo P, Peak GL, Gielen AC, McDonnell KA, Trochim WM. An introduction to concept mapping as a participatory public health research method. Qual Health Res. 2005 Dec;15(10):1392-410. Pubmed PMID: 16263919.

[16]. Parikh ND. Effectiveness of teaching through mind mapping technique. The International Journal of Indian Psychology. 2016;3(3):148-56.

[17]. Rojak HA. Upaya Meningkatan Hasil Belajar Siswa melalui Model Mind Mapping (Ptk pada Siswa Kelas IX B SMPN 3 Kota Cirebon). Edunomic Jurnal Pendidikan Ekonomi. 2016 Mar 1;4(1).

[18]. Nurlaila AP. The use of mind mapping technique in writing descriptive text. Journal of English and Education. 2013;1(2):9-15.

[19]. T. Buzan, The Ultimate Book of Mind Maps. 2012.

[20]. D. D. Nurika.Pengaruh Pendidikan Kesehatan dengan Metode Mind Mapping terhadap Kemampuan Anak dalam Merawat Skabies di Yayasan Pondok Pesantren Darul Istiqomah Azainiyah Antirogo. Jember, 2014.

[21]. Jones BD, Ruff C, Snyder JD, Petrich B, Koonce C. The effects of mind mapping activities on students' motivation. International Journal for the Scholarship of Teaching and Learning. 2012;6(1).

[22]. D. Porter, Bobbi.Quantum Teaching. Bandung: KAIFA, 2011.

[23]. Wati ML, Siswati S. Pengaruh metode mind map terhadap peningkatan hasil belajar mata pelajaran ilmu pengetahuan alam terpadu pada siswa kelas VII. Empati. 2015 Oct 31;4(4):131-8.

[24]. Aein F, Aliakbari F. Effectiveness of concept mapping and traditional linear nursing care plans on critical thinking skills in clinical pediatric nursing course. J Educ Health Promot. 2017 Apr 19;6:13. Pubmed PMID: 28546978.

[25]. YMTakus."Pengaruh Penerapan Metode Eksperimen Berbantu Mind Mapping Terhadap Peningkatan Pengetahuan, Minat Belajar, dan Kerjasama Siswa Kelas Xi Mipa SMA Negeri 1 Ngaglik Pada Materi Pembiasan Cahaya Pada Lensa Cembung Tahun Ajaran 2017/201,” 2018.

[26]. Muzdalifah V. The use of mind mapping to improve the descriptive text writing abilities of the 10th grade students. Unpublished Thesis, English Department, UNESA, Surabaya. 2008.

[27]. Solso RL, MacLin OH, MacLin MK. Cognitive psychology: Pearson new international edition. Pearson; 2013 Oct 3. 